\title{
The Effect of PGPR (Plant Growth Promoting Rhizobacteria) Concentration on Growth and Yield of Red Bean (Phaseolus vulgaris L.)
}

\author{
Rd. Budiasih ${ }^{1}$, Suparman ${ }^{2}$, Linlin Parlinah ${ }^{3}$, Wiwin Kurniawati ${ }^{4}$ \\ \{budiasihenty@gmail.com ${ }^{1}$, suparman.ir@gmail.com ${ }^{2}$, linlinparlinah@gmail.com ${ }^{3}$ \} \\ Major of Agrotechnology, Faculty of Agriculture, Winaya Mukti University ${ }^{1}$
}

\begin{abstract}
Bacteria that live around plant roots that sparked the growth of plants or Plant Growth Promoting Rhizobacteria (PGPR) are bacteria that are beneficial to the soil which forms colonies on roots and planting areas can enhance plant growth. One of the areas of plant roots is the root of the plant area of red beans (Phaseolus vulgaris 1.). This article aims to study the influence of the concentration of PGPR (plant growth Promoting Rhizobacteria) and best influence on growth and yield of red bean crops. This research was conducted in the village of Tanjungsari Subdistrict, Sumedang Regency, with an altitude of 870 meters above sea level and is carried out from May to July 2018. The design of the treatment used is Simple Random Design patterns Group consisting of 6 treatment and in repeated 4 times. Moderate is the solution $\mathrm{A}=0 \mathrm{ml} \mathrm{L}-1$ solution, $\mathrm{B}=5$ $\mathrm{ml} \mathrm{L}-1$ solution, $\mathrm{C}=10 \mathrm{ml} \mathrm{L}-1$ solution, $\mathrm{D}=15 \mathrm{ml} \mathrm{L}-1$ solution, $\mathrm{E}=20 \mathrm{ml} \mathrm{L}-1$ solution and $\mathrm{F}=25 \mathrm{ml} \mathrm{L}-1$ solution. The parameters observed were higher plants $(\mathrm{cm})$, number of leaves (blades), the number of pods (fruits), the number of seeds (fruits), wet weight of pods $(\mathrm{g})$ dried pods, weights $(\mathrm{g})$, the wet seed weight $(\mathrm{g})$ and the dry seed weight $(\mathrm{g})$. The results showed that the concentration of the granting of PGPR has no effect against plant height at the age of 14 days after planting (DAP) and the number of leaves on each treatment. But giving influence on plant height at age 28 and 42 DAP, the number of pods, number of seeds, the weight of the wet, heavy pea pods dry, wet, and heavyweight of the seeds dry. The concentration of PGPR in $15 \mathrm{ml} \mathrm{L}-1$ treatments have the best effect for the red bean crops.
\end{abstract}

Keyword: Red Beans, PGPR (Plant Growth Promoting Rhizobacter

\section{Introduction}

Production of red bean plants (Phaseolus vulgaris L) in Indonesia based on the Badan Pusat Statistik (BPS) in 2018 is decreased when compared with production in 2017 [1], so as to continue to increase the production of red bean plants It takes some efforts such as the utilization of microbes as biological agents producing certain compounds that can enhance plant growth and environmentally friendly fertilizer such as fertilizer biological and organic fertilizer.

The use of plant growth Promoting Rhizobakteri (PGPR) as biological fertilizer is one contribution of biotechnology in an attempt to increase crop productivity. Results the results showed the awarding of PGPR is able to inhibit the growth of s. rolfsii and reduce the percentage of occurrence of diseases fall sprouts improve germination and the growth of soybean plants [2], and gives the effect on growth and crop yield peanuts [3]. 
The advantages of PGPR is able to suppress the growth of pests and diseases such as b. subtilis produces isoform lipopeptida with potential antifungal compounds [4] grant of rizobakteri p. fluorescens lowers the number of nematodes Meloidogyne incognita eggs and pressing the intensity of kenaf plant disease [5], p. fluorescens effective controlling nematodes attack the roots of puru (m. javanica) as well as being able to enhance the growth of tomato plants [6], p. fluorescens and Bacillus subtilis is able to control the virus infection Eggplant yellow [7], Pseudomonas fluorescens and b. subtilis is able to inhibit the growth of Rhizoctonia solani miselia germination and disease-causing leaf blight in rice plant [8], $\mathrm{p}$. fluorescens and $b$. subtilis bacteria can be applied in improvement of the environment contaminated by nicosulfuron [9]. B. subtilis is able to reduce the number of nematode and improve crops carrot [10]. Enzyme kitinase produced by flurescens mematika pest capable Psedomonas Helopeltis spp pests in the tea plantation [11].

Research results penamban rizobakteri (Bacillus cereus, b. subtilis, and Serratia sp) able to control fusarium wilt and increase harvest tomato plants in the ground Ultisol [12], the application of the formulation of the spores of $b$. subtilis can press the leaf blight disease up to $21 \%$ and potentially increase yields by up to $50 \%$ of the rice plant. [13] PGPR single isolates of $b$. subtilis and p. fluorescens and Azotobacter sp., as well as the combination of $b$. subtilis, p. fluorescens, and Azotobacter SP. can increase the number of pods and pods of peanut wet weights, but only the application of $b$. subtilis a can increase the weight of dried peas ground nuts. [14], rhizobakteri (Bacillus SP., Pseudomonas SP., Azotobacter SP., Azospirillum SP., and Aspergillus sp.) has a number of pods a lot more but have a size smaller than a control, in addition rhizobakteri has a strike rate of treatment pests and diseases in vegetable soybean plants rather than the control. [15]

As for the purpose of this research is to study the influence of the concentration of PGPR (b. subtilis and p. fluorescens) towards growth and red bean crops. To learn the most best PGPR concentration towards growth and crop yield beans (Phaseolus vulgaris L.)

\section{Methods}

This research uses experimental methods by experimenting in the field in a poly bag. The experiment was carried out on JL. Heulang Cape Hamlet Citali Village Warehouse Sumedang Tanjungsari sub district, with an altitude of $870 \mathrm{~m}$ place above sea level. The experiment conducted in May to July 2018.

The materials used include red bean seeds, soil, fertilizer NPK Phonska, chicken manure, PGPR combination of bacterial isolates of $b$. subtilis and Pseudomonas fluorecens, insecticide Decis 2.5 EC and extracts of sweet potato. The tools used are polybag, hoes, knives, cutting boards, Jerry cans, hose connection hose to the Aquarium, the shape of a T and L, aerator, glass wool, PK (Potassium Permanganate), candles/night, bottle of minerals, gas, stove, pots, buckets, ropes rapia, paper, stationery, basin, clear plastic, camera, measuring cup, hand sprayer and nameplate experiment, measuring instrument such as a ruler, thermometer and analytical scales.

The design of the experiment is a random Design Group simple patterns, consisting of 6 treatment concentration of PGPR which is repeated 4 times. Each treatment consisted of 5 poly bag, bringing the total to be 120 polybag. PGPR concentration treatment consists of: $\mathrm{A}=$ $0 \mathrm{ml} \mathrm{L}-1$ solution, $\mathrm{B}=5 \mathrm{ml} \mathrm{L}-1$ solution, $\mathrm{C}=10 \mathrm{ml} \mathrm{L}-1$ solution, $\mathrm{D}=15 \mathrm{ml} \mathrm{L}-1$ solution, $\mathrm{E}=$ $20 \mathrm{ml} \mathrm{L}-1$ solution and $\mathrm{F}=25 \mathrm{ml} \mathrm{L}-1$ solution. The observed variables are composed of plants 
(cm) height, number of leaves (blades), the number of pods (fruits), the number of seeds (fruits), wet weight of pods (g) dried pods, weights $(\mathrm{g})$ wet weight, $(\mathrm{g})$ and the dry seed weight per plant $(\mathrm{g})$.

\section{Result}

\subsection{Plant growth}

The results of the analysis in table 1. shows PGPR treatment influence different unreal without treatment at age 14 DAP. It is alleged to be caused by several factors, namely the early plant growth has not been able to absorb the nutrient elements optimally and rooting not growing perfectly so that the plant hasn't been able to absorb the nutrient elements provided optimally as well as the availability of organic materials decomposition results hara against plants require relatively long time. While at the age of 28 and 42 day after planting (DAP) shows different real influence because rooting has been developing optimally, so the plant roots are able to absorb a given nutrient elements and elements available nutrient in the soil. B. subtilis is a plant growth boosters rhizobacterium build strong interactions with roots of beneficial to utilize carbon-rich root exudate, which can facilitate the colonization of rhizobacterial and reciprocal links with plant. [16] the volatile organic Compounds. produced by b. subtilis enhance growth with sparking growth hormone activity on tomato plants [17].

Tabel 1. Response to high average growth of plants and the number of Leaves at the age of 14 DAP and 28 DAP and 42 DAP against the concentration of PGPR (Plant Growth Promoting Rhizobacteria).

\begin{tabular}{lcccccc}
\hline \multirow{2}{*}{ Treatment } & \multicolumn{3}{c}{ Average Plant Height (cm) } & \multicolumn{2}{c}{ Average number of leaves (strands) } \\
\cline { 2 - 7 } & 14 DAP & 28 DAP & 42 DAP & 14 DAP & 28 DAP & 42 DAP \\
\hline $\mathrm{A}\left(0 \mathrm{ml} \mathrm{L}^{-1}\right)$ & $11,94 \mathrm{a}$ & $25,94 \mathrm{ab}$ & $29,44 \mathrm{a}$ & $1,63 \mathrm{a}$ & $6,63 \mathrm{a}$ & $10,75 \mathrm{a}$ \\
$\mathrm{B}\left(5 \mathrm{ml} \mathrm{L}^{-1}\right)$ & $11,88 \mathrm{a}$ & $27,50 \mathrm{ab}$ & $31,88 \mathrm{ab}$ & $1,88 \mathrm{a}$ & $7,13 \mathrm{a}$ & $10,88 \mathrm{a}$ \\
$\mathrm{C}\left(10 \mathrm{ml} \mathrm{L}^{-1}\right)$ & $12,44 \mathrm{a}$ & $28,19 \mathrm{~b}$ & $30,13 \mathrm{a}$ & $1,75 \mathrm{a}$ & $7,00 \mathrm{a}$ & $11,13 \mathrm{a}$ \\
$\mathrm{D}\left(15 \mathrm{ml} \mathrm{L}^{-1}\right)$ & $11,44 \mathrm{a}$ & $22,81 \mathrm{a}$ & $27,00 \mathrm{a}$ & $1,38 \mathrm{a}$ & $5,75 \mathrm{a}$ & $8,63 \mathrm{a}$ \\
$\mathrm{E}\left(20 \mathrm{ml} \mathrm{L}^{-1}\right)$ & $12,69 \mathrm{a}$ & $25,69 \mathrm{ab}$ & $31,00 \mathrm{ab}$ & $1,75 \mathrm{a}$ & $7,50 \mathrm{a}$ & $11,13 \mathrm{a}$ \\
$\mathrm{F}\left(25 \mathrm{ml} \mathrm{L}^{-1}\right)$ & $11,94 \mathrm{a}$ & $28,69 \mathrm{~b}$ & $35,94 \mathrm{~b}$ & $1,63 \mathrm{a}$ & $6,75 \mathrm{a}$ & $10,75 \mathrm{a}$ \\
\hline
\end{tabular}

Description: Average treatment are marked with the same in the same column shows the different unreal based on Multiple Distance Test Duncan at $5 \%$ level.

Granting of PGPR (Plant Growth Promoting Rhizobacteria) exert influence are not real against the number of leaves on each treatment (table 1). This is allegedly because there are other pathogen in soil medium are used so that the work function of PGPR as biostimulant hampered or excessive Powers, which according to et.al. [18] the interactions between microbial compounds produced that many considered antibiotics can have an impact on the development of subinhibitory concentrations of bacteria on. 
Tabel 2. Response Ratarata Results number of pods, number of seeds, Pods, Wet Weights Weights Plong dry, Damp, Seed Weight and Seed Dry Weight per Plant against concentration of PGPR (Plant Growth Promoting Rhizobacteria)

\begin{tabular}{lcccccc}
\hline Treatment & $\begin{array}{c}\text { The number of } \\
\text { Pods (fruits) }\end{array}$ & $\begin{array}{c}\text { The number of } \\
\text { seeds (fruits) }\end{array}$ & $\begin{array}{c}\text { Wet Pods } \\
\text { weights (g) }\end{array}$ & $\begin{array}{c}\text { Dried Pods } \\
\text { weights (g) }\end{array}$ & $\begin{array}{c}\text { Wet Seed } \\
\text { weight }(\mathbf{g})\end{array}$ & $\begin{array}{c}\text { The dry Seed } \\
\text { weight }(\mathbf{g})\end{array}$ \\
\hline $\mathrm{A}\left(0 \mathrm{ml} \mathrm{L}^{-1}\right)$ & $3.75 \mathrm{a}$ & $9.38 \mathrm{a}$ & $14.28 \mathrm{a}$ & $4.34 \mathrm{a}$ & $6.19 \mathrm{a}$ & $2.19 \mathrm{a}$ \\
$\mathrm{B}\left(5 \mathrm{ml} \mathrm{L}^{-1}\right)$ & $3.88 \mathrm{a}$ & $10.38 \mathrm{a}$ & $13.47 \mathrm{a}$ & $4.96 \mathrm{a}$ & $5.93 \mathrm{a}$ & $2.95 \mathrm{ab}$ \\
$\mathrm{C}\left(10 \mathrm{ml} \mathrm{L}^{-1}\right)$ & $3.88 \mathrm{a}$ & $11.63 \mathrm{a}$ & $14.26 \mathrm{a}$ & $4.61 \mathrm{a}$ & $6.75 \mathrm{a}$ & $3.00 \mathrm{ab}$ \\
$\mathrm{D}\left(15 \mathrm{ml} \mathrm{L}^{-1}\right)$ & $6.38 \mathrm{~b}$ & $17.25 \mathrm{~b}$ & $24.82 \mathrm{~b}$ & $7.68 \mathrm{~b}$ & $10.78 \mathrm{~b}$ & $4.73 \mathrm{~b}$ \\
$\mathrm{E}\left(20 \mathrm{ml} \mathrm{L}^{-1}\right)$ & $2.88 \mathrm{a}$ & $9.25 \mathrm{a}$ & $11.05 \mathrm{a}$ & $3.65 \mathrm{a}$ & $5.24 \mathrm{a}$ & $2.41 \mathrm{a}$ \\
$\mathrm{F}\left(25 \mathrm{ml} \mathrm{L}^{-1}\right)$ & $3.38 \mathrm{a}$ & $9.88 \mathrm{a}$ & $14.86 \mathrm{a}$ & $4.94 \mathrm{a}$ & $6.26 \mathrm{a}$ & $3.06 \mathrm{ab}$ \\
\hline
\end{tabular}

Description: Average treatment are marked with the same in the same column shows the different unreal based on Multiple Distance Test Duncan at 5\% level.

\subsection{Crop Yield}

The results of the analysis range on the giving of PGPR real influence against the result of red bean plants (table 2). According to Syamala and Sivaji [19] Psedomonas flurescens and b. subtilis produce salicylic acid, IAA and solvents glukanase phosphate, also produces the enzyme pektinase and kitinase [20] so that the role of Psedomonas flurescens and b. subtilis as PGPR very According to increase crop production.

At the treatment $15 \mathrm{ml} \mathrm{L}-1$, which provides the best results against which the amount of parameters number of pods, seeds, legumes, wet weights weights pods dry, wet seed weights and seed dry weight, as reported by Halmedan, et.al [21], the granting of PGPR (Bacillus SP. and $\mathrm{p}$. fluorescens) were able to improve the results of sweet corn and the best treatment of $b$. subtilis and p. fluorescens. significantly increased the total yield of cucumber. [22] the b. subtilis is able to plant biomass and imningkatkan synthesis of fotosntesis pigment plant beans on conditions copy. [23]

\section{Conclution}

The experiment results show that concentrations of PGPR (Plant Growth Promoting Rhizobacteria) which applicated give effect on plant height at age 28 DAP and DAP 42, against the number of pods, number of seeds, peas weight wet, dried pods, weight weight of wet, dry seed weight per plant. The concentration of PGPR (Plant Growth Promoting Rhizobacteria) on treatment $15 \mathrm{ml} \mathrm{L}-1$ gives the best results against the influence of red bean plants. 


\section{References}

[1] BPS, "Tabel Dinamis Produksi Tanaman Sayuran Kacang Merah,” Badan Pusat Statistik, 2018. [Online]. Available: bps.go.id.

[2] M. Sofiani, S. Djauhari, and L. Q. Aini, "Pengaruh Aplikasi Plant Growth Promoting Rhizobacteria (PGPR) dalam Menghambat Penyakit Rebah Kecambah yang Disebabkan oleh Jamur Sclerotium rolfsii pada Kedelai,” J. HPT, vol. 4, no. 1, pp. 32-38, 2016.

[3] N. Marom, Rizal, and M. Bintoro, "Uji Efektivitas Waktu Pemberian dan Konsentrasi PGPR ( Plant Growth Promoting Rhizobacteria ) Terhadap Produksi dan Mutu Benih Kacang Tanah (Arachis hypogaea L .),” J. Appl. Agric. Sci., vol. 1, no. 2, pp. 174-184, 2017.

[4] I. Mnif et al., "Purification and Identification of Bacillus subtilis SPB1 Lipopeptide Biosurfactant Exhibiting Antifungal Activity Against Rhizoctonia bataticola and Rhizoctonia solani," Env. Sci Pollut Res, 2015.

[5] K. S. Wijayanti, B. T. Rahardjo, and U. Brawijaya, "Pengaruh PGPR terhadap Penekanan Populasi Nematoda Puru Akar ( Meloidogyne incognita (Kofoid and White) Chitwood) pada Tanaman Kenaf ( Hibiscus cannabinus L.),” Bul. Tanam. Tembakau, vol. 8, no. 1, pp. 30-39, 2016.

[6] A. P. Damayanti, B. T. Rahardjo, and H. Tarno, "Pengaruh Pemberian Plant Growth Promoting Rhizobacteria ( Psudomonas fluorescens ) terhadap Nematoda Puru Akar Meloidogyne sp. Pada Tanaman Tomat," J. HPT, vol. 6, no. 1, pp. 26-34, 2018.

[7] Mursiana, N. Aidawati, and G. M. S. Noor, "Kemampuan Beberapa Rizobakteria dalam Mengendalikan Penyakit Kuning pada Pertumbuhan Tanaman Terong ( Solanum melongena L )," Prot. Tanam. Trop., vol. 1, no. 02, pp. 8-11, 2018.

[8] S. Nagendran, S. Kulanthaivelu, and T. Sundararajan, "Assessment on Antagonistic Potential of Bacterial bio Agents Pseudomonas fluorescens and Bacillus subtilis Against Rhizoctonia solani Kühn . An Incitant of Sheath Blight of Rice,” J. Entomol. Zool. Stud., vol. 7, no. 3, pp. 128-142, 2019.

[9] A. Sunulahpašić, S. Hamidović, S. Mitrić, T. Gavrić, S. Haseljić, and B. Lalević, “Assessment of Microbial Diversity of Soil Exposed to Nicosulfuron," Zast. Mater., vol. 60, pp. 152-156, 2019.

[10] M. S. Rao et al., "Scientia Horticulturae Bacillus subtilis IIHR BS-2 enriched vermicompost controls root knot nematode and soft rot disease complex in carrot," Sci. Hortic. (Amsterdam)., vol. 218, pp. 56-62, 2017.

[11] M. Suganthi, P. Senthilkumar, S. Arvinth, and K. N. Chandrashekara, "Chitinase from Pseudomonas fluorescens and its Insecticidal Activity Against Helopeltis theivora," J. Gen. Appl. Microbiol., vol. 11, pp. 1-6, 2016.

[12] A. Khaeruni, A. Wahab, M. Taufik, and G. Sutariati, "Keefektifan Waktu Aplikasi Formulasi Rizobakteri Indigenus untuk Mengendalikan Layu Fusarium dan Meningkatkan Hasil Tanaman Tomat di Tanah Ultisol ( The Effectiveness of Application Time of Indigenous Rhizobacteria Formulation to Control Fusarium Wilt and," J. Hort, vol. 23, no. 4, pp. 365-371, 2013.

[13] Wartono, Giyanto, and K. H. Mutaqin, "Efektivitas Formulasi Spora Bacillus subtilis B12 sebagai Agen Pengendali Hayati Penyakit Hawar Daun Bakteri pada Tanaman Padi,” Penelit. Pertan. Tanam. Pangan, vol. 34, no. 1, pp. 21-28, 2015.

[14] L. E. Febriyanti, M. Martosudiro, and T. Hadiastono, "Pengaruh Plant Growth Promoting Rhizobacteria (PGPR) terhadap Infeksi Peanut Stripe Virus (PStV), Pertumbuhan dan Produksi Tanaman Kacang Tanah (Arachis hypogea L.,) Varietas Gajah,” J. HPT, vol. 3, no. 1, pp. 2338-4336, 2015. 
[15] F. M. Ardiyanto, A. S. Karyawati, and S. M. Sitompul, "Pengaruh Frekuensi Pemberian Rhizobacteria Pemacu Pertumbuhan Tanaman Terhadap Pertumbuhan dan Hasil Kedelai Sayur (Glycine max L. Merrill),” J. Produksi Tanam., vol. 5, no. 11, pp. 1762-1767, 2017.

[16] R. Allard-massicotte et al., "Bacillus subtilis Early Colonization of Arabidopsis thaliana Roots Involves Multiple Chemotaxis Receptors,” MBio, vol. 7, no. 6, pp. 1-10, 2016.

[17] H. A. S. Tahir et al., "Plant Growth Promotion by Volatile Organic Compounds Produced by Bacillus subtilis SYST2," Front. Microbiol., vol. 8, pp. 1-11, 2017.

[18] M. J. Powers, E. Sanabria-Valentin, A. A. Bowers, and E. A. Shank, "Inhibition of Cell Differentiation in Bacillus subtilis by Pseudomonas protegens," J. Bacteriol., vol. 197, no. 13, pp. 2129-2138, 2015.

[19] M. Syamala and M. Sivaji, "Functional characterization of various plant growth promoting activity of Pseudomonas fluorescens and Bacillus subtilis from Aloe vera rhizosphere," J. Pharmacogn. Phytochem., vol. 6, no. 3, pp. 120-122, 2017.

[20] R. S. R. El-Mohamedy, N. G. El-Gamal, A. R. El-Shamy, and S. M. M. Atalla, "Biosynthesis of Zinc Nanoparticles and Its Effect on Enzymes Production by Bacillus subtilis and Pseudomonus flourescens Using Different Agricultural Wastes,” Int. J. Agric. Technol., vol. 14, no. 6, pp. 833-844, 2018.

[21] J. Halmedan, Y. Sugito, and Sudiarso, "Respon Tanaman Jagung Manis (Zea mays saccharata) Terhadap Aplikasi Plant Growth Promoting Rhizobacteria (PGPR) dan Pupuk Kandang Ayam,” J. Produksi Tanam., vol. 5, no. 12, pp. 1926-1935, 2017.

[22] D. A. Al-khafaji and F. A. Al-fadhal, "Effect of Bacillus subtilis and Pseudomonas fluorescens in reducing cucumber seed rot and seedlings death caused by Rhizoctonia solani and Fusarium solaniin green house conditions," Kufa J. Agric. Sci., vol. 11, no. 1, pp. 12-25, 2019.

[23] E. F. Abd_Allah et al., "Endophytic Bacterium Bacillus subtilis ( BERA 71 ) Improves Salt tolerance in Chickpea Plants by Regulating the Plant Defense Mechanisms," J. Plant Interact., vol. 13, no. 1, pp. 37-44, 2018. 